\title{
SOCIO-ECONOMIC PROFILE AND PERCEPTION OF PEPPER SMALLHOLDERS ON THE USE OF INFORMATION TECHNOLOGY
}

\author{
Novyandra Ilham Bahtera ${ }^{\left.{ }^{*}\right)}$, Evahelda $^{1)}$, Eddy Jajang Jaya Atmaja ${ }^{1)}$, Riko Irwanto ${ }^{2)}$ \\ ${ }^{1}$ Agribusiness Department, Universitas Bangka Belitung, 33172, Indonesia \\ ${ }^{2}$ Biology Department, Universitas Bangka Belitung, 33172, Indonesia \\ *Corresponding author: novyandra@ubb.ac.id
}

To cite this article:

Bahtera, N., Evahelda, E., Atmaja, E., \& Irwanto, R. (2021). Socio-Economic Profile and Perception of Pepper Smallholders on the Use of Information Technology. JIA (Jurnal Ilmiah Agribisnis) : Jurnal Agribisnis dan IImu Sosial Ekonomi Pertanian, 6(3), 93 - 97. doi:http://dx.doi.org/10.37149/jia.v6i3.17840

Received: April 23, 2021; Accepted: June 20, 2021; Published: June 24, 2021

\begin{abstract}
The economic growth in the agriculture sector contributes to the income of the Bangka Belitung Island Province. In the few decades, pepper production in Indonesia retains its position as one of the biggest producers in the world. However, pepper production in the province goes down. Consequently, the income of pepper farmers reduces. Understanding the farmers' demographic and their perception of the technology acceptance model will help policymakers provide the best empowerment program and agricultural support program to uplift their welfare. The study aims to understand the socio-economic profile and the perception of pepper farmers towards the technology acceptance model using information technology in pepper farming activity. The data collection process was conducted from August to November 2019. Structured questionnaires and face-to-face data collection methods were applied to earn the primary data from 100 pepper smallholders in Bangka Tengah and Bangka Selatan, Bangka Belitung Island Province. Descriptive analysis was used to identify the respondents' profiles and explain their skills and awareness to adopt information technology in their farming activity. The study revealed that most of the pepper farmers were in the average age of 45 years old, held elementary school level, received income of about 5.7 million, was experienced farmers with 20 years of pepper farming activity, and had about $2.1-5$ ha of land area. The majority of the pepper smallholders offered low scores to the proportion of perceived usefulness and perceived ease of use. The results benefit the policymaker and farmer in providing a better farming activity and offering the best program to empower pepper farmers.
\end{abstract}

Keywords: Bangka Island; information technology marketing practice; pepper farmers

\section{INTRODUCTION}

In the last three decades, the average of pepper production in Indonesia remains the top producer globally, counted 67,725 ton indicating the different 8,223 ton with the second-highest pepper production in the world, Vietnam (Nuryati \& Noviati, 2015). Even though Indonesia, on average, maintains the position as the top producer globally, starting from 2004, the pepper production of Vietnam has taken over Indonesia's pepper production counted 95,420 tons and 77,008 tons, respectively (FAO, 2019). It leads to the condition that Vietnam becomes the world's leading exporter (Kementan, 2015).

The study of the socio-economic profile of pepper Farmers in Indonesia is relatively insufficient. Most of the tasks which research in Indonesia attempt to identify the socio-economic profile of oil palm farmers (Laure, 2010; Bahtera, 2016), food crop farmers (Andri, 2014), rice farmers (Wulandari, 2013), horticulture farmers (Naibaho, Fauzia, \& Emalisa, 2012) even at oversea, i.e., in India about potato farmers (Rana et al., 2014), and chili farmers (Biradar \& Chandrgi, 2013). The new business model currently shows how customers are more open to demand their needs and become the decision-maker on their ideal product (Peszko, 2015). It makes customers more aware of the received benefit from the source of the new business model, offering accessible and reliable information about their product. To attract potential buyers to buy a particular product, the producers require adapting their marketing practices with the new business model. As the grand theory, the 
technology acceptance model is used in this study to know producers' readiness in using the technology. Perceived usefulness and perceived ease of use are two variables that identify the attitude of technology use (Davis, 1986). Below is the figure that shows those variables mentioned.

Understanding the pepper Farmers' socio-economic profile is vital as it can be used as the information for policymaker on the strategy of disseminating the use of information technology on the marketing practices. Thus, the study's objective is to identify the socio-economic profile of pepper Farmers and the perceived benefit and perceived usefulness towards their attitude on the use of information technology in their marketing practices.

\section{MATERIALS AND METHODS}

The study was conducted from August to November 2019. Data and information were obtained from 100 Pepper Farmers in Central and South Bangka. A structured questionnaire was designed by completing the face-to-face data collection method. The questionnaire consisted of questions asking the socio-economic profile such as age, education, income, years of farming, and farming size. The survey also asked about the perceived usefulness, perceived ease of use, and attitude of pepper Farmers towards using information technology in their marketing practices. The trained enumerators facilitated the respondents in answering the five-point Likert-scale questions ranging from strongly disagree to agree strongly. Descriptive analysis was applied to know the pepper farmer's socio-economic profile and describe their abilities and awareness to adapt the information technology in their farming activity.

\section{RESULTS AND DISCUSSION}

\section{Socio-Economic Profile of Respondent}

Table 1: Socio-economic profile of respondent

\begin{tabular}{|c|c|c|c|c|}
\hline Variable & Frequency & Percentage & Mean & SD \\
\hline Age & & & 46 & 12.1 \\
\hline $25-35$ & 21 & 21 & & \\
\hline $36-45$ & 33 & 33 & & \\
\hline $46-55$ & 28 & 28 & & \\
\hline $56-65$ & 13 & 13 & & \\
\hline$>65$ & 5 & 5 & & \\
\hline \multicolumn{5}{|l|}{ Education } \\
\hline Non-Formal Education & 11 & 11 & & \\
\hline Elementary School & 47 & 47 & & \\
\hline Junior High School & 16 & 16 & & \\
\hline Senior High School & 21 & 21 & & \\
\hline Diploma & 3 & 3 & & \\
\hline Degree & 2 & 2 & & \\
\hline Monthly Income (IDR) & & & $5,766,558$ & $7,402,356$ \\
\hline$<700$ thousand & 1 & 1 & & \\
\hline 701 thousand -1.4 million & 12 & 12 & & \\
\hline 1.41 million - 3.5 million & 37 & 37 & & \\
\hline 3.51 million - 7 million & 28 & 28 & & \\
\hline$>7$ million & 22 & 22 & & \\
\hline Years of Farming & & & 20.5 & 13.2 \\
\hline $1-10$ & 29 & 29 & & \\
\hline $11-20$ & 35 & 35 & & \\
\hline $21-30$ & 21 & 21 & & \\
\hline $31-40$ & 7 & 7 & & \\
\hline $41-50$ & 5 & 5 & & \\
\hline$>51$ & 3 & 3 & & \\
\hline \multicolumn{5}{|l|}{ Farming Size (ha) } \\
\hline$<2$ & 24 & 24 & & \\
\hline $2.1-5$ & 59 & 59 & & \\
\hline $5.1-10$ & 17 & 17 & & \\
\hline
\end{tabular}


Table 1 showed that 25 - 73 years old was the range of the pepper Farmers' age while 46 years old was the mean age with a standard deviation of 12.1 years old. $33 \%$ of respondents were between 36 and 45 years old, $28 \%$ between 46 and 55 years old, and $21 \%$ between 25 and 35 . It explained that most farmers were around the productivity age, which was around 40s years old (O'Connell, 2013, Bahtera, 2016).

In terms of educational background, the majority of respondents held only elementary school education (47\%), only $2 \%$ and $3 \%$ have a university degree and a diploma degree respectively, 11 $\%$ had non-formal education, $16 \%$ received junior high school education, and $21 \%$ achieved senior high school education. It described that most of the pepper Farmers had a low level of education. It was also similar condition with the livestock smallholders in Bangka Belitung Island Province (Yulia, Bahtera, Herdiyanti, \& Hayati, 2020)

On average, the household's monthly income was counted at IDR5,766,558 with a standard deviation of IDR7,402,356. About one-third of respondents acquired between 1.41 million and 3.5 million Rupiah per month, and almost one-fourth of them received monthly income at more than IDR7 million. Only $1 \%$ and $12 \%$ of respondents gained income per month less than 700 thousand Rupiah and 701 thousand - 1.4 million Rupiah, respectively. It indicated that most respondents lived in the lower-middle-income class poverty line based on World Bank's definition. The smallholder's skills in entrepreneurship were required to eradicate poverty on pepper farmers (Astuti, Bahtera, \& Atmaja, 2019, 2020).

$35 \%$ of respondents were relatively experienced farmers who had spent $11-20$ years in the pepper commodity, $29 \%$ and $21 \%$ stated $1-10$ years and $21-30$ years, respectively. These data suggested that most of the pepper Farmers were upper intermediate level in pepper farming. Furthermore, in terms of farming size, the majority of pepper Farmers (59\%) had $2.1-5$ ha, close to one-fourth of the respondents ( $24 \%$ ) had less than 2 ha, and the rest of them (17\%) owned $5.1-10$ ha. Therefore, it indicated that most of the respondents had a small amount of farming area.

Table 2 Level of Perception and Attitude towards the Information Technology $(n=100)$

\begin{tabular}{lcc}
\hline \multicolumn{1}{c}{ Level } & Frequency & Percentage (\%) \\
\hline Perceived Usefulness & & \\
Low & 55 & 55 \\
Moderate & 28 & 28 \\
High & 17 & 17 \\
\hline Perceived Ease of Use & & \\
Low & 49 & 49 \\
Moderate & 25 & 25 \\
High & 26 & 26 \\
\hline Attitude towards Using & & \\
Low & 60 & 60 \\
Moderate & 26 & 26 \\
High & 14 & 14 \\
\hline
\end{tabular}

Table 2 illustrated the perception and attitude of 100 farmers towards information technology use in marketing practices. There were three variables provided in Table 2, which were: perceived usefulness, perceived ease of use, and attitude towards using. Each variable showed a similar pattern that the most dominant level was low, followed by moderate and high level accept perceived ease of use, which was quite similar between middle and high class, 25 and 26 respectively.

The first variable showed in Table 2 was perceived usefulness. It consisted of using the Internet in the marketing practices such as helping in providing information about pepper and weather forecasts, supporting in a business transaction, saving time, gaining more profit, and improving productivity. $55 \%$ of respondents were at the low level, while $28 \%$ and $17 \%$ were at moderate and high levels, respectively. It indicated that most farmers considered that using the Internet in the marketing practices was still not familiar. It was due to most of them were at a low level of education. The smallholders tend not to use technology in marketing and farming activities (Bahtera, Evahelda, Atmaja, Setiawan, \& Irwanto, 2019). The Internet was used in the education sector to play (Budiyani \& Sujarwo, 2019; Shahibi \& Rusli, 2017) and not play an important role (Krismant, 2002).

The second variable figured in Table 2 was perceived ease of use. It explained the perception of farmers on the easiness of using the Internet to support agribusiness activity. Seven statements were provided on the questionnaire. The questions were about how easy the Internet was to be used by farmers in their farming activity. The statements were basically about easy learning using the 
Internet, facilitating farmers in the farming activity, strong internet connection, user-friendly application on gadgets, affordable price of data packages, accessibility in purchasing data packages, and the ability to use the Internet. Table 2 illustrated that almost half of respondents were low on the perceived ease of use. At the same time, about a quarter of respondents went to moderate level (25 $\%)$ and high level (26\%). It explained that most respondents considered the Internet as challenging to use as the age of farmers considered the digital immigrant. The years of age can affect the adult's social life (Zhang \& Kaufman, 2015), and often the elders tend to be excluded in the digital era (Van Deursen \& Helsper, 2015)

\section{CONCLUSIONS}

The study's objective was to describe the socio-economic profile of the pepper smallholders and their perception towards the use of information technology in their farming activity in Bangka Tengah and Bangka Selatan. The study revealed that the average age of the smallholders was 46 years old, earned a monthly income of $\mathrm{Rp} 5,700,000$, considered as experienced pepper smallholders with 20 years of experience in pepper farming activity, mostly had farmland about $2.1-5$ ha and acquired low level of education with elementary school holder in average. The majority of the pepper smallholders classified perceived usefulness, perceived ease of use, and attitude towards using as skeptical about the information technology in pepper farming activity. The findings offered valuable information to the stakeholders to support more relevant and needed a program to uplift the economic situation faced by the smallholders. The local government might use the study's discovery to solve the empowerment program and agriculture support program, which could help the smallholders strengthen their position in the global trade of pepper. It suggested that the farmer group institution should be maintained to create a solid bond to support each other (Bahtera \& Hayati, 2018). Participation in agriculture support programs should be applied by improving smallholders' knowledge to gain better practices (Bahtera, Arshad, Sidique, Djama, \& Abu-Samah, 2016).

\section{ACKNOWLEDGMENTS}

We want to thank Universitas Bangka Belitung for moral and financial support on the study process through Faculty Level of Lecturer Research (Indonesian: Hibah Penelitian Dosen Tingkat Fakultas).

\section{REFERENCES}

Andri, K. B. (2014). Socio-Economic Profile And Character Of Food Crop Farmers In Bojonegoro. Agriekonomika, 3(2), 171-183.

Astuti, R. P., Bahtera, N. I., \& Atmaja, E. J. J. (2019). Entrepreneurial Characteristics and Behaviors of Muntok White Pepper Farmers. Society, 7(2), 101-115. https://doi.org/10.33019/society.v7i2.116

Astuti, R. P., Bahtera, N. I., \& Atmaja, E. J. J. (2020). The contribution of Business Environment Factor in Forming the Entrepreneurial Characteristics of White Pepper Smallholders. IOP Conference Series: Earth and Environmental Science, 599(1). https://doi.org/10.1088/1755$1315 / 599 / 1 / 012077$

Bahtera, N. I. (2016). Socio-Economic Profile And Perception Of Smallholders Towards The Empowerment Program In Tanjung Jabung Barat, Indonesia. Asia Business and Economics Journal, 2(1), 27-35.

Bahtera, N. I., Arshad, F. M., Sidique, S. F., Djama, M., \& Abu-Samah, A. (2016). The determinants of participation in empowerment programs in Jambi province, Indonesia. Asia Pacific Institute of Advanced Research, 2(2), 534-550.

Bahtera, N. I., Evahelda, E., Atmaja, E. J. J., Setiawan, I., \& Irwanto, R. (2019). the Technology Acceptance Model (Tam) on Pepper Farmers in Bangka, Indonesia. Journal of Information System and Technology Management, 4(15), 48-58. https://doi.org/10.35631/jistm.415005

Bahtera, N. I., \& Hayati, L. (2018). Understanding the Social Capital of Coffee Smallholders on the Coffee-Growing Activities in Pagar Alam, Indonesia. International Journal of Modern Trends in Social Sciences, 1(5), 1-9.

Biradar, B. S., \& Chandrgi, D. M. (2013). Socio-Economic Profile of Chilli Farmers and their Constraints in Chilli Cultivation in North-Eastern districts of Karnataka G S Biradar and DM Chandrgi. Research Journal of Agricultural Sciences, 4, 661-666. 
Budiyani, W., \& Sujarwo. (2019). The Impact of Internet Application As Resource of Learning on Students' Independence. In 3rd English Language and Literature International Conference (ELLiC) (Vol. 3, pp. 7-12).

Davis, F. D. (1986). A technology acceptance model for empirically testing new end-user information systems: Theory and results. Management, Ph.D.(April), 291. https://doi.org/oclc/56932490

FAO. (2019). FAOStat. Retrieved from http://www.fao.org/faostat/en/

Kementan. (2015). Komoditas Pertanian Subsektor Tanaman Pangan Padi, 103.

Krismant, W. (2002). The effects of internet-based teaching and learning systems on learners. King Mongkut's Institute of Technology North Bangkok' 1518 Piboonsongkhram Rd., Bangsue, Bangkok 10800, Thailand, (June), 1-12.

Laure, L. R. (2010). The livelihood impacts of oil palm: smallholders in Indonesia, 1009-1024. https://doi.org/10.1007/s10531-010-9815-z

Naibaho, T. T., Fauzia, L., \& Emalisa. (2012). The influence of the farmer's economic, social factors on producing a green mustard farm business. Jurnal IImiah, 1-16.

Nuryati, L., \& Noviati. (2015). Outlook Lada. Jakarta.

Peszko, K. (2015). the Consumer As a Source of Marketing Information in the Information Society. Central Bohemia University International Conference Proceedings 2015 Innovations in Science and Education, 3, 361-367. https://doi.org/10.12955/cbup.v3.625

Rana, R. K., Sharma, N., Arya, S., Kadian, M. S., Singh, B. P., \& Pandey, S. K. (2014). Status of potato farming and farmer's socio-economic profile in moisture and heat prone karnataka, India, 51(1), 7-16.

Shahibi, M. S., \& Rusli, K. N. K. K. (2017). The Influence of Internet Usage on Studentâ $\square^{\mathrm{TM}} \mathbf{s}$ Academic Performance. International Journal of Academic Research in Business and Social Sciences, 7(8), 873-887. https://doi.org/10.6007/ijarbss/v7-i8/3301

van Deursen, A. J. A. M., \& Helsper, E. J. (2015). A nuanced understanding of Internet use and nonuse among the elderly. European Journal of Communication, 30(2), 171-187. https://doi.org/10.1177/0267323115578059

Wulandari. (2013). Socio-Economic Condition of Rice Field Farmers Of Mangalli, Palangga District, Gowa Regency. Hasanuddin University.

Yulia, Bahtera, N. I., Herdiyanti, \& Hayati, L. (2020). An alternative policy of livestock farmers' empowerment towards an environmental vision. IOP Conference Series: Earth and Environmental Science, 599(1). https://doi.org/10.1088/1755-1315/599/1/012076

Zhang, F., \& Kaufman, D. (2015). Social and Emotional Impacts of Internet Use on Older Adults. European Scientific Journal, ESJ, 11(17), 1-15. 